\title{
Pengaruh Konseling Kelompok dalam Meningkatkan Motivasi Belajar Siswa KMS di SMP N 5 Yogyakarta
}

\author{
Zaldhi Yusuf Akbar \\ ${ }^{1}$ Fakultas Psikologi Universitas Muhammadiyah Purwokerto \\ zaldhi@ump.ac.id
}

\begin{abstract}
Abstrak
SMP Negeri 5 Yogyakarta menerima siswa-siswa kurang mampu atau siswa KMS. Siswa KMS SMPN 5 kelas 8 berjumlah 15 orang. Terdapat permasalahan pada siswasiswa KMS. Siswa KMS memiliki motivasi yang kurang, prestasi akademik yang rendah Berdasarkan survey awal Guru BK mengatakan bahwa siswa KMS pada kelas VIII menunjukan motivasi belajar yang rendah. Siswa KMS pun jarang aktif ketika pelajaran KBM berlangsung.. Ini juga dikuatkan dengan data FGD terhadap siswa kms yang memiliki motivasi rendah dan prestasi kurang baik. Dalam hal ini penelitian tentang siswa kms sangat menarik untuk diteliti. Metode penelitian eksperiman dengan skala motivasi belajar untuk pretest, post test dan follow up test, Penghitungan menggunakan aplikasi SPSS 17 for windows diketahui bahwa nilai t untuk pretest sebesar 39.762 dan untuk posttest sebesar 53.469. Adapun hasil uji beda menunjukkan signifikansi $p=0,004 \quad(p<0,005)$. Kesimpulannya konseling kelompok yang dilakukan mampu meningkatkan skor motivasi belajar siswa secara signifikan.
\end{abstract}

Kata kunci: Konseling kelompok, Motivasi, Siswa KMS.

\section{Pendahuluan}

Pendidikan memiliki tujuan. Tujuan dapat diartikan sebagai suatu usaha untuk memberikan rumusan hasil yang diharapkan siswa setelah melaksanakan pengalaman belajar (Sardiman,2014). Tercapainya dapat terlihat dari prestasi yang diraih. Dengan prestasi yang baik, para siswa mempunyai indikasi berpengatahuan tinggi. Salah satu faktor yang berpengaruh selain prestasi siswa adalah motivasi. Dengan adanya motivasi, siswa akan belajar lebih keras, ulet, tekun dan memiliki konsentrasi penuh dalam proses belajar pembelajaran. Dorongan motivasi dalam belajar merupakan salah satu hal yang perlu dibangunkan dalam upaya pembelajaran di sekolah. 
PSISULA: Prosiding Berkala Psikologi

Vol. 1, 2019

E-ISSN: $2715-002 X$

Belajar merupakan suatu pengalaman yang diperoleh berkat adanya interaksi antara individu dengan lingkungannya. Belajar menunjukkan suatu proses perubahan perilaku atau pribadi seseorang. Belajar merupakan tugas utama setiap siswa. Untuk bisa belajar diperlukan motivasi. Motivasi dan belajar saling mempengaruhi. Motivasi berperan strategis dalam aktivitas belajar seseorang. Tidak ada seseorang yang belajar tanpa motivasi. Tidak ada motivasi berarti tidak ada kegiatan belajar. Agar peranan motivasi lebih optimal, maka prinsip-prinsip motivasi dalam belajar tidak hanya sekadar diketahui, tetapi harus diterangkan dalam aktivitas belajar mengajar.

Motivasi adalah suatu kondisi dalam diri yang memiliki kekuatan atau daya untuk bergerak, mendorong individu untuk melakukan sesuatu untuk mencapai tujuan. Seperti yang diungkapkan Sardiman (2014) bahwa motivasi dirangsang karena adanya tujuan. Terdapat dua jenis motivasi, yaitu motivasi intrinsik dan motivasi ektrinsik. Motivasi intrinsik adalah motivasi yang muncul dari dalam diri siswa. Baik muncul secara alami atas keinginan siswa atau bahkan karena dorongan dari luar diri individu. Dari lingkungan pembelajaran yang paling berperan memberikan motivasi belajar adalah guru.

Setyowati (2007) menjelaskan bahwa terdapat pengaruh yang signifikan motivasi belajar terhadap hasil belajar siswa. Siswa yang memiliki motivasi tinggi dalam belajar memungkinkan akan memperoleh hasil belajar yang lebih tinggi pula, artinya semakin tinggi motivasinya semakin intensitas usaha dan upaya yang dilakukan, maka semakin tinggi hasil belajar yang diperolehnya.

Siswa melakukan usaha untuk meningkatkan keberhasilan dalam belajar sehingga mencapai keberhasilan yang cukup memuaskan sebagaimana yang diharapkan. Disamping itu motivasi juga menopang upaya-upaya dan menjaga agar proses belajar siswa tetap jalan. Hal ini dijadikan siswa gigih dalam belajar.

SMP Negeri 5 Yogyakarta menerima siswa-siswa kurang mampu atau siswa KMS. Siswa KMS SMPN 5 kelas 8 berjumlah 15 orang. Terdapat permasalahan pada siswa-siswa KMS. Siswa KMS memiliki motivasi yang kurang, prestasi akademik yang 
PSISULA: Prosiding Berkala Psikologi

Vol. 1, 2019

E-ISSN: $2715-002 X$

rendah. Berdasarkan survey awal Guru BK mengatakan bahwa siswa KMS pada kelas VIII menunjukan motivasi belajar yang rendah. Siswa KMS pun jarang aktif ketika pelajaran KBM berlangsung. Ini juga dikuatkan dengan data FGD terhadap siswa kms yang memiliki motivasi rendah dan prestasi kurang baik. Berdasakan data survey awal menemukan penelitian bahwa Penelitian tentang konseling kelompok dapat meningkatkan motivasi belajar telah dilakukan oleh ahli yaitu Campbell dan Brigman (2005) dalam penelitiannya tentang konseling kelompok pada siswa sekolah menengah dapat disimpulkan bahwa kelompok yang diberikan konseling kelompok dapat meningkat prestasi belajar dan kertampilan manajemen diri dimana didalamnya termasyuk motivasi belajar. Penelitian Aulia pada siswa SMA kelas II menunjukan bahwa konseling kelompok dapat meningkatkan motivasi belajar siswa yang mengalami ketidaksesuaian pilihan dengan bidang jurusan.

Pemilihan konseling kelompok dengan alasan bahwa konseling kelompok merupakan tipe konseling yang dilakukan dengan kolompok yang focus pertamanya membantu seseorang dalam memecahkan masalah hidupnya seperti yang dikemukakan oleh Romano dan D'Rozario (Tan, 2004). Oleh karena itu pendekatan konseling kelompok ini tepat untuk siswa yang memiliki permasalahan dengan motivasi belajar, sebab motivasi belajar dalam kegiatan belajar mengajar di sekolah adalah bagian dari persoalan hidup dan merupakan salah satu problematika yang selalu ada di sekolah. Konseling kelompok disarankan pada siswa remaja karena pada usia ini dorongan dan dukungan satu dengan yang lain dengan teman sebaya sangat kuat (Brown dan Lent, 2005). Focus perhatian dalam konseling kelompok adalah dukungan moral dari anggota dengan cara membuka diri (Self Disclosure) dengan melakukan diskusi dan menceritakan pengalaman yang dialami, dan cara mengatasi permasalahan yang dialami.

Gibbon (2009) mengungkapkan bahwa banyak pandangan akan meningkatkan kemungkinan respon yang baru dan lengkap, ide-ide atau solusi secara signifikan. Salah satu metode yang digunakan dalam pendekatan kelompok adalah sharing. Sharing informasi dalam kelompok lebih efektif terutama ketika ada inovasi yang 
PSISULA: Prosiding Berkala Psikologi

Vol. 1, 2019

E-ISSN: $2715-002 X$

timbul dari peserta kemudian informasi yang ada segera dibagikan digunakan tanpa membutuhkan komunikasi yang rumit. Menurut Prawitasari (1991), konseling kelompok dapat membantu individu untuk memahami perasaan dalam dirinya dan hubungannya dengan orang lain serta pengembangan pribadinya. Interaksi kelompok dapat terjadi proses umpan balik, proses belajar dan berlatih perilaku baru, belajar mengekspresikan perasaan, saling memberikan bantuan dan perhatian serta memberikan kesempatan mempelajari ketrampilan sosial. Selain itu untuk menyelesaikan masalahnya remaja membutuhkan dukungan sosial dalam bentuk dukungan emosional, empati, simpati dan penghargaan. Hal ini dapat diperoleh melalui suasana konseling kelompok yang memberikan peluang pada para siswa untuk belajar behubungan dengan orang lain. Berdasarkan rumusan masalah diatas maka dapat dirumuskan tujuan penelitian ini adalah untuk mengetahui apakah Konseling Kelompok dapat meningkatkan motivasi belajar siswa KMS.

\section{Metode}

Metode penelitian yang digunakan adalah Kuantitatif eksperimen, dengan penentuan sample dengan teknik sampel purposive berdasarkan karakteristik subjek seperti siswa KMS dan kelas VIII.

\section{Hasil Penelitian}

Pendekatan yang digunakan pada konseling ini adalah pendekatran kognitif. Pendekatan kognitif berupaya memfokuskan untuk menempatkan suatu pikiran, keyakinan atau bentuk pembicaraan diri sendiri terhadap orang lain. Dengan kata lain, pendekatan ini memfokuskan pada kegiatan mengelola dan memonitor pola pikir siswa sehingga dapat mengurangi pikiran negative dan mengubah isi pikiran agar dapat diperoleh emosi yang lebih positif (Slavin, 2006). Pendekatan kognitif juga menyatakan bahwa semua kejadian dan situasi di sekeliling kita diterima dan diproses dalam otak manusia menjadi persepsi. Persepsi dapat timbul dari referensi yang sudah dipelajari. Persepsi dapat menimbulkan konsekuensi emosional karena 
PSISULA: Prosiding Berkala Psikologi

Vol. 1, 2019

E-ISSN: $2715-002 X$

arti yang diberikan dan menjadi motivasi untuk bertindak dan berperilaku. Persepsi yang timbul dapat menyimpang atau keliru maka konsekuensinya emosionalnya menjadi negatif.

Perlakuan yang diberikan kepada kelompok eksperimen adalah berupa konseling kelompok. Adapun materi yang akan disampaikan pada konseling kelompok tersebut merujuk pada modul konseling Aulia (2007) dan Modul Konseling Susilo (2013). Pengambilan materi berdasarkan data yang di dapatkan dan karakteristik SMPN 5 yang dalam penerimaan siswa yang di terima nilai UN tidak terlalu berbeda dengan siswa regular sehingga dari data yang saya dapatkan sehingga intervensi kelompok ini menggunakan metode Action Research. Menurut Mertler (2014) metode ini menyesuaikan keadaan siswa, waktu siswa dan keterbutuhan siswa sehingga semua siswa bisa mengikuti konseling kelompok ini. Modul disesuaikan dengan siswa sehingga modul adalah sesi-sesi yang dibutuhkan oleh siswa. Sesi dalam konseling kelompok ini akan disesuaikan dengan kebutuhan siswa. Konseling kolompok akan diadakan 1 kali dalam setiap minggu dengan alokasi waktu bervariasi. Ada 4 sesi, setiap minggu diadakan 1 kali pertemuan, dengan durasi waktu yang bervariasi antara 90-120 menit per sesi

Adapun materi yang disampaikan dalam konseling keolompok yaitu

a. Membangun kedekatan (Susilo, 2013), pada tahap ini bertujuan untuk:

1. membentuk kelompok dan mengenal antar anggota kelompok dengan fasilitator.

2. memberikan kesempatan kepada anggota untuk berbagi rasa dan pengalaman, serta belajar terbuka dalam menerima umpan balik.

b. Pemahaman diri (Aulia, 2007), pada tahap ini bertujuan:

1. semua anggota kelompok dapat membuat daftar mengenai kelebihan dan kekurangan masing-masing.

2. memberikan kesempatan kepada anggota untuk lebih mengenal dirinya (anggota kelompok mengetahui kelebihan dan kekurangan masing-masing. Kegiatan yang dilakukan adalah dengan memberikan tugas individu "Siapa 
PSISULA: Prosiding Berkala Psikologi

Vol. 1, 2019

E-ISSN: $2715-002 X$

Aku" pada peserta untuk menuliskan pada lembar kerja tentang kelebihan, kekurangan, minat, kemampuan serta prestasi peserta selama mengikuti kegiatan belajar mengajar. Setelah peserta menyelesaikan tugasnya, dilanjutkan dengan sharing tentang dirinya agar peserta lain mengetahui dan memberikan masukan untuk kebaikan peserta.

c. Agenda belajarku (Aulia, 2007), tahap ini bertujuan:

1. memberikan pemahaman tentang pentingnya belajar

2. memberikan kesempatan kepada anggota dalam menentukan agenda masalah belajar masing-masing

3. masing-masing anggota menetapkan target perubahan yang ingin dicapai

4. memberikan kesempatan belajar dan berlatih bagi semua anggota kelompok untuk mengatasi agenda masalah belajarnya dalam interaksi kelompok. Pada sesi ini peserta diberikan lembar kerja, tiap peserta dimohon untuk mengisi kolom tentang agenda belajar yang berisi tentang permasalahan belajar, penyebab permasalahan, target yang ingin dicapai dan usaha yang telah dilakukan. Setelah semua peserta mengisi lembar kerja, kemudian dilanjutkan dengan sharing antar peserta tentang apa yang ditulisnya.

d. Kelompokku (Aulia, 2007), pada tahap ini bertujuan:

1. peserta dapat mengeksplorasi upya untuk mengatasi permasalahan

2. peserta dapat mengeksplorasi tentang upaya lain solusi dar peserta lain

3. peserta menemukan insight setelah melakukan sharing dengan peserta lain. Sesi pembukaan sesama anggota kelompok dan anggota tim yang terlibat dalam konseling kelompok mengenalkan diri terlebih dahulu, menyampaikan tentang tujuan dan harapan atau agenda yang akan dituntaskan dan kontrak belajar selama konseling. Sesi pengenalan diri peserta memiliki kesempatan untuk lebih mengenal diri, sesi agenda belajar, peserta diminta memetakan masalah belajar masng-masing dan menentukan tempat perubahan yang ingin dicapai dilanjutkan dalam materi kelompok peserta diminta untuk sharing dengan teman-temannya tentang masalah belajar dan target perubahannya. Sesi figurku peserta dapat 
PSISULA: Prosiding Berkala Psikologi

Vol. 1, 2019

E-ISSN: $2715-002 X$

mengambil manfaat dari tokoh yang dihadirkan. Sesi aku yang akan datang peserta diminta untuk berbagi dengan teman-teman tentang manfaat yang diambil dari film dan tokoh yang dihadirkan.

Setelah empat sesi berakhir dan sebelum konseling kelompok ditutup, peserta dberikan lembar evaluasi secara tertulis, yang bertujuan untuk menetapkan masukan dari peserta mengenai proses pelaksanaan konseling secara keseluruhan, meliputi materi yang disampaikan, kemampuan fasilitator dalam menyimpulkan materi, proses konseling kelompok dan fasilitas selama konseling kelompok.

Konseling kelompok diatas diberikan dalam 2x pertemuan, yaitu 1 kali diminggu pertama dan 1 kali diminggu kedua. Setiap pertemuan membutuhkan waktu 90-120 menit. Tujuan Konseling kelompok ini adalah meningkatkan motivasi belajar siswa. Evaluasi hasil dilakukan dengan membandingkan tingkat motivasi belajar siswa sebelum (pretest) dan sesudah (posttest) konseling kelompok. Pretest dilakukan pada tanggal 28 dan 29 Januari 2016 dan posttest dilakukan pada tanggal 27 Februari 2016 pada sesi penutupan konseling kelompok. Adapun Follow Up dilakukan satu bulan setelah pelaksanaan intervensi pada tanggal 31 Maret 2016.

Penghitungan menggunakan aplikasi SPSS 17 for windows diketahui bahwa nilai t untuk pretest sebesar 39.762 dan untuk posttest sebesar 53.469. Adapun hasil uji beda menunjukkan signifikansi $p=0,004 \quad(p<0,005)$. Artinya konseling kelompok yang dilakukan mampu meningkatkan skor motivasi belajar siswa secara signifikan. Adapun data follow up menunjukkan bahwa motivasi siswa tetap bertahan dalam waktu satu bulan, namun tidak ada perubahan signifikan dan diketahui bahwa nilai t untuk postest sebesar 53.469 dan untuk follow up sebesar 63.000. ditunjukan dengan hasil uji beda menunjukkan signifikansi $p=0,220$ $(p<0,005)$ namun terdapat 5 siswa yang menunjukkan peningkatan motivasi belajar, sementara itu 2 siswa lain walaupun mengalami penurunan motivasi belajar tetapi tidak lebih rendah dibandingkan data pretest. 
PSISULA: Prosiding Berkala Psikologi

Vol. 1, 2019

E-ISSN: 2715-002X

Tabel 1. Hasil Pretest, Postest dan Follow up

\begin{tabular}{cccccccc}
\hline No & Nama & $\begin{array}{c}\text { Skor } \\
\text { Pretest }\end{array}$ & Kategori & $\begin{array}{c}\text { Skor } \\
\text { Postest }\end{array}$ & Kategori & $\begin{array}{c}\text { Skor Follow } \\
\text { up }\end{array}$ & Kategori \\
\hline 1 & TW & 119 & Rendah & $130(+11)$ & Sedang & $128(-2)$ & Sedang \\
2 & HM & 112 & Rendah & $127(+15)$ & Sedang & $128(+1)$ & Sedang \\
3 & HMP & 138 & Sedang & $148(+10)$ & Tinggi & $150(+2)$ & Sedang \\
4 & MA & 131 & Sedang & $136(+5)$ & Sedang & $147(+9)$ & Sedang \\
5 & K & 145 & Sedang & $149(+4)$ & Sedang & $159(+10)$ & Tinggi \\
6 & FEY & 138 & Sedang & $143(+5)$ & Sedang & $144(+1)$ & Sedang \\
7 & IQ & 112 & Rendah & $145(+33)$ & Sedang & $142(-3)$ & Sedang \\
\hline
\end{tabular}

Tabel 2. Hasil secara kualitatif

\begin{tabular}{|c|c|c|}
\hline No & Nama & Hasil Kualitatif \\
\hline 1 & TW & $\begin{array}{l}\text { Dapat dilihat dari data hasil pretest sampai follow up, TW mengalami skor } \\
\text { motivasi belajar yang meningkat sebanyak } 9 \text { poin, meskipun skornya menurun } \\
\text { setelah postest Sehingga didapatkan kesimpulan konseling kelompok dapat } \\
\text { meningkatkan motivasi belajar siswa kms }\end{array}$ \\
\hline 2 & $\mathrm{HM}$ & $\begin{array}{l}\text { Dapat dilihat dari data hasil pretest sampai follow up, TW mengalami skor } \\
\text { motivasi belajar yang meningkat sebanyak } 16 \text { poin. Sehingga didapatkan } \\
\text { kesimpulan konseling kelompok dapat meningkatkan motivasi belajar siswa } \\
\text { kms }\end{array}$ \\
\hline 3 & HMP & $\begin{array}{l}\text { Dapat dilihat dari data hasil pretest sampai follow up, TW mengalami skor } \\
\text { motivasi belajar yang meningkat sebanyak } 12 \text { poin. Sehingga didapatkan } \\
\text { kesimpulan konseling kelompok dapat meningkatkan motivasi belajar siswa } \\
\text { kms }\end{array}$ \\
\hline 4 & MA & $\begin{array}{l}\text { Dapat dilihat dari data hasil pretest sampai follow up, TW mengalami skor } \\
\text { motivasi belajar yang meningkat sebanyak } 14 \text { poin. Sehingga didapatkan } \\
\text { kesimpulan konseling kelompok dapat meningkatkan motivasi belajar siswa } \\
\text { kms }\end{array}$ \\
\hline 5 & K & $\begin{array}{l}\text { Dapat dilihat dari data hasil pretest sampai follow up, TW mengalami skor } \\
\text { motivasi belajar yang meningkat sebanyak } 14 \text { poin. Sehingga didapatkan } \\
\text { kesimpulan konseling kelompok dapat meningkatkan motivasi belajar siswa } \\
\text { kms }\end{array}$ \\
\hline 6 & FEY & $\begin{array}{l}\text { Dapat dilihat dari data hasil pretest sampai follow up, TW mengalami skor } \\
\text { motivasi belajar yang meningkat sebanyak } 6 \text { poin. Sehingga didapatkan } \\
\text { kesimpulan konseling kelompok dapat meningkatkan motivasi belajar siswa } \\
\text { kms }\end{array}$ \\
\hline 7 & IQ & $\begin{array}{l}\text { Dapat dilihat dari data hasil pretest sampai follow up, TW mengalami skor } \\
\text { motivasi belajar yang meningkat sebanyak } 30 \text { poin, meskipun kemudian } \\
\text { skornya menurun ketika postest sehingga didapatkan kesimpulan konseling } \\
\text { kelompok dapat meningkatkan motivasi belajar siswa kms }\end{array}$ \\
\hline
\end{tabular}




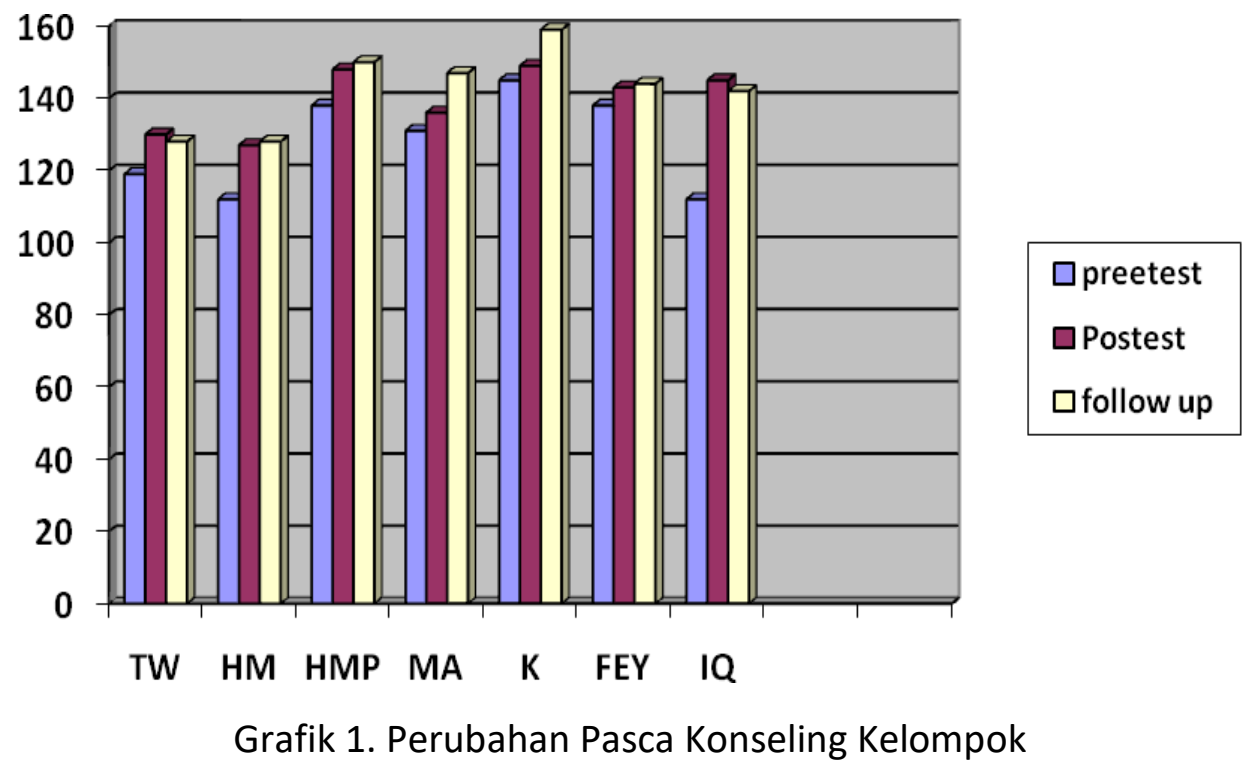

\section{Diskusi}

Permasalahan yang dialami oleh siswa KMS dikarenakan beberapa siswa KMS merasa bahwa di SMPN 5 para siswa tidak dapat mengoptimalkan potensinya dikarenakan beberapa karena bersekolah di SMPN 5 bukan merupakan pilihan awal dari para siswa kemudian ada yang kesulitan dalam jarak ke sekolah yang jauh. Ditambah lagi siswa merasa pelajaran di SMP berbeda dengan SD. Para siswa membutuhkan penjelasan yang lebih detail namun guru cenderung kurang memfasilitasi.

Siswa tidak memiliki jam pelajaran sendiri sehingga ketika tidak mengerti dengan pelajaran di kelas siswa cenderung tidak belajar dikarenakan tidak memahami pelajaran. Para siswa KMS dengan nilai rendah malas sehingga para siswa merasa dengan datang bersekolah sudah dianggap cukup. Pada kasus SMPN 5 ini diketahui terlihat bahwa tidak adaya upaya yang keras dari siswa KMS untuk melakukan belajar secara rutin dan tidak pernah bertanya kepada guru atau teman sekelas yang memiliki kemampuan dalam pelajaran yang tidak dikuasai oleh siswa KMS ini.

Berdasarkan hasil penelitian yang dilakukan oleh Wang, Haertel, dan Welberg, 1993 (Pearson, Hinson dan Brown, 2001) tampak jelas bahwa ada hubungan yang 
PSISULA: Prosiding Berkala Psikologi

Vol. 1, 2019

E-ISSN: $2715-002 X$

positif antara motivasi dan prestasi. Menurut Keith Mitchell (Pintrich dan Schuck, 1986) motivasi dapat mempengaruhi pelajaran performance baru yang dipelajari di kelas, strategi dan perilaku yang akan memberikan implikasi penting di sekolah.

Pintrinch, Mark dan Boyle (1993) mengemukakan dalam penelitiannya bahwa motivasi merupakan factor penting yang dapat meningkatkan atau menurunkan hasil belajar siswa. Motivasi yang dimaksudkan mengacu pada kesediaan siswa, kebutuhan, keinginan dan dorongan untuk berprestasi dalam belajar, sehinga motivasi dapat membantu siswa terlibat kegiatan di kelas yang akan meningkatkan dan menurunkan hasil belajar siswa.

Atkinson (Slavin, 2006) mendefinisikan motivasi sebagai keyakinan seseorang untuk mencapai keberhasilan tergantung probabilitas untuk sukses dan intensif.Probabilitas untuk sukses adalah keyakinan individu tentang seberapa besar peluang dirinya untuk mendapatkan hasil melalui respon yang mampu dia lakukan. Nilai-nilai intensif dari sukses adalah kebanggaan yang dirasakan atas sukses yang dicapainya.

Faktor-faktor yang dapat menyebabkan motivasi dalam diri seseorang itu tinggi atau rendah Atkinson (Slavin, 2006). Faktor-faktor tersebut yaitu : probabilitas untuk sukses dan nilai insentif. Tugas terlalu mudah untuk diatasi tidak menghasilkan banyak kebanggaan dan sangat tidak menarik dan lebih membanggakan ketika individu sukses menyelesaikannya. Seseorang yang memiliki motivasi belajar tinggi menurut Djiwandono (2002) akan memiliki ciri-ciri seperti:

1. Merespon dan merasa tertantang terhadap tugas-tugas yang diberikan oleh guru

2. Memperoleh nilai yang tinggi

3. Dapat memberikan umpan balik dengan jitu dan benar

4. Menyampaikan masalah-masalah baru.

Sebaliknya seorang yang memiliki motivasi belajar rendah akan memiliki ciri-ciri:

1. Akan merespon pekerjaan yang kurang menantang

2. Membutuhkan banyak penguat untuk dapat sukses 
PSISULA: Prosiding Berkala Psikologi

Vol. 1, 2019

E-ISSN: $2715-002 X$

3. Membuat langkah-langkah kecil dalam belajar, memerlukan nilai-nilai yang toleran.

4. Menghindari orang lain menghindari kesalahan.

Didapatkan kesimpulan bahwa motivasi belajar dapat mempengaruhi hasil belajar dan mempengaruhi pelajaran dan ketrampilan baru yang dipelajari di kelas.Motivasi belajar dapat diartikan sebagai suatu keyakinan pada diri seseorang untuk mencapai keberhasilan. Keberhasilan dipengaruhi oleh dua factor yaitu seberapa besar peluang dirinya untuk mendapatkan hasil melalui respon yang mampu ia lakukan dan kebanggaan yang dirasakan atas sukses yanjg dicapainya (Slavin, 2006)

\section{Kesimpulan}

Skor skala motivasi belajar seluruh peserta konseling kelompok mengalami peningkatan. Hasil uji statistik membuktikan adanya perbedaan nilai pretest dan posttest. skor posttest lebih tinggi dibandingkan skor pretest. Untuk hasil follow up skor yang didapatkan ada kenaikan. Ada dua siswa yang skor follow up nya menurun namun tidak lebih rendah dibandingkan pretest. Dapat disimpulkan bahwa konseling kelompok dapat meningkatkan motivasi belajar Siswa KMS.

\section{Daftar Pustaka}

Aulia, (2007). Efektivitas Konseling Kelompok untuk Meningkatkan Motivasi Belajar Siswa SMA Kelas 11 IPS yang Mengalami Ketidaksesuaian Pilihan dengan Bidang Jurusan. (Thesis tidak diterbitkan). Fakultas Piskologi Universitas Gadjah Mada. Yogyakarta.

Campbell, C.A. \& Brignan, G. (2005). Closing the Achievement Gap: A Structured Approach to Group Counseling. The Journal For Spesialist in Group Work, Vol. 30 No $1,67-82$.

Djiwandono S. A.W. (2002). Psikologi Pendidikan. Jakarta: PT Gramedia Widiasrana Indonesia.

Gibbon, T. (2009). Group Coaching in Organisation. Its Time has come: A process for applied learning. Team Management System. Diunduh pada tanggal 17 
PSISULA: Prosiding Berkala Psikologi

Vol. 1, 2019

E-ISSN: $2715-002 X$

Januari 2016 dari: Http://www.tms-americas.com/pdfs/Group Coaching in Organizatios.pdf.

Glynn, S.M., Aultman, L.P., \& Owens, A.M. (2005). Motivation to Learn in General Education Programs. The Journal of general Education: 54(2), 150-170.

Pearson, R.D,, Hinson, S.L., \& Brown, D.S. (2001). Educational Psychology. Canada: Wadsworth.

Pintrinch, P.R., Mark, R.W., \& Boyle, R.A. (1993). Beyond Cold Conceptual Change: The Role of Motivational Beliefes and Classroom Contextual Factors in the Prosess of Conceptual change. Review of Educational Research, 63, 169-199.

Pintrich, P.R \& Schuck, D.H.(1996). Motivation In Educational. New Jarsey: Englewood Cliffs.

Prawitasari, J.E (1991). Pendekatan kelompok dalam konseling dan Psikoterapi. Malang: Ikip Malang.

Santrock, J. W. (2007). Educational Psychology. Boston : McGraw-Hill

Sardiman, A.M. (2014). Interaksi \& Motivasi Belajar Mengajar. Jakarta: PT Raja Grafindo Persada.

Setyowati. (2007). Pengaruh Motivasi Belajar Terhadap Hasil Belajar Siswa Kelas VII SMPN 13 Semarang.Skripsi. Semarang: Universitas Negeri Semarang.

Slavin, R.E (2006) Psikologi Pendidikan Jilid 1. Penterjemah: Marianto Samosir: Jakarta: PT. Indek.

Suseno, Joko. (2013). Konseling Kelompok untuk meningkatkan Motivasi Belajar siswa SMP.Thesis (tidak diterbitkan). Fakultas Psikologi UGM

Tan, E.(2004). Counseling in School. Theories, Processes and Techniques. Singapura: McGraw Hill. Inc 